\title{
BLACK TERN NEST-SITE FIDELITY IN AN UNSTABLE HABITAT: A PRELIMINARY STUDY
}

\author{
N. S. Atamas ${ }^{1 \star}$, O. V. Tomchenko ${ }^{2}$ \\ ${ }^{1}$ Schmalhausen Institute of Zoology NAS of Ukraine, \\ vul. B. Khmelnytskogo, 15, Kyiv, 01030 Ukraine \\ E-mail: atamasnataly@gmail.com \\ ${ }^{2}$ Scientific Centre for Aerospace Research of the Earth Institute of Geological Science, National Academy of \\ Sciences of Ukraine, \\ O. Gonchara st., 55-b, Kyiv, 01601 Ukraine \\ E-mail: tomch@i.ua \\ ${ }^{*}$ Corresponding author
}

Atamas N. S. (https://orcid.org/0000-0002-1072-8826)

Tomchenko O. V. (https://orcid.org/0000-0001-6975-9099)

Black Tern Nest-site Fidelity in an Unstable Habitat: a Preliminary Study. Atamas, N. S., Tomchenko, O. V. - We investigated the return rate and nest-site fidelity of adult Black Terns (Chlidonias niger) in unstable habitats at the Kaniv reservoir, Middle Dnipro (Dnieper), Ukraine, where regular weather extremes such as heavy rains and storms lead to a destruction of nesting colonies. 278 adult birds were tagged with colored rings in 12 Black Tern colonies during the nesting season in 2012-2019. 44 Black Terns were resighted or recaptured in eight colonies. The return rate was $15.8 \%$ and it declined rapidly within the first three years after ringing. 29 returning terns were noted within the same colonies where the birds had been tagged initially, 15 ones were seen in other colonies, but the majority of them were found no farther than $2 \mathrm{~km}$ from the original colony. The mean site fidelity rate was $66 \%$. Olgin colony showed a high nest-site fidelity rate, while it was much lower in the others. Such variations occurred because of the loss of the first clutches caused by unfavorable weather conditions. In the middle of May high waves, storms and heavy rains regularly destroyed nesting colonies located in habitats poorly protected by water plant vegetation. Terns relocated their colonies to re-nest but commonly not farther than $2 \mathrm{~km}$ from their original colonies.

Key worlds:Black Tern Chlidonias niger, ringing, nest-site fidelity, return rate, Ukraine. 


\section{Introduction}

Nest-site fidelity is the tendency of adult birds to return to the same nesting area for breeding every year (Coulson, 2016). It is assumed that this behavior benefits birds in a number of ways, such as from exploitation of previously used feeding habitats, low pressure of predators and having information about available nest sites (McNicholl, 1975; Greenwood, 1982; Bried, Jouventin, 2001), so it is particularly important for wetland water birds.

The larids inhabiting stable habitats on rocks, have a high level of site tenacity. Conversely, those species which nest in unstable habitats are less conservative in choosing their breeding sites (McNicholl, 1975; Switzer, 1993; Francesiaz et al., 2017; Sanchez, 2004). Among larids, marsh terns (Chlidonias spp.) prefer unstable habitats, such as floodplains, river deltas, meadows and bog habitats frequently damaged by water during floods, heavy rains and storms or, conversely, by dry weather and dewatering.

In Ukraine, the Black Tern (Chlidonias niger) mostly nests at pond farms, oxbows and other lakes in floodplains, drainage canals, eutrophic and marsh lakes, overgrown areas of water reservoirs (Bokotey et al., 2010; Dzyubenko, 2005; Atamas', 2011). Some of those habitats are repeatedly destabilized by weather conditions, flooding, drying out and other destructive seasonal phenomena.

In Ukraine, one of the largest nesting populations of Black Terns is located at the water reservoirs of the Middle Dnipro and Dnipro river basin. The surveyed group of colonies consists of several stable large colonies in the northern fluvial part of the Kaniv water reservoir. Compared to the southern part of the reservoir, there are no significant daily and seasonal fluctuations of the water level. However, the nesting sites of Black Terns can also be influenced by crashing waves and strong storms. Thus, such nesting habitats are less predictable in comparison with the canals in the Netherlands or the lakes in Germany (van der Winden et al., 2004; Meier-Peithmann, 2005). To test a prediction that Black Tern should display less site fidelity for unstable habitats, adult birds were banded in colonies at the fluvial part of the Kaniv water reservoir with color marked plastic leg-flags during 2012-2019. Thus, the present work is aimed at giving a preliminary assessment for the dispersal, nest-site fidelity and return rate of Black Tern under the conditions of unstable nesting habitats.

\section{Material and methods}

The study was conducted at the Black Tern nesting colonies in the northern fluvial part of the Kaniv water reservoir, between Kyiv City and Kyiliv village (Kyiv Region, Obukhiv District). Finding colonies, capturing, banding and resighting of ringed terns were done during the breeding season starting from the first ten days of May till the last ten days of July. Surveys were conducted on a canoe.

During 2012-2019, the birds were captured using automatically closing over-nest catching boxes. The birds were marked with metal C-shape rings and INTERREX white plastic leg-flags with a two-letter code, and since 2018 - with leg-flags engraved with a number and a letter code. Besides, basic measurements and samples of DNA and blood were taken.

During the 2013-2019 breeding seasons we searched for color-marked terns at the colonies by scanning nesting and flying disturbed birds and catching ones at the nests.

The observations of the banded birds were done by means of the Nikon D90 camera with lens Nikkor AF 400 mn f5.6, Olympus 10x50 binoculars and Opticron MM4 Spotting Scope Kits. For better reading of leg-flags, two bird colonies were fitted with horizontal and vertical sticks to provide resting places.

We summarized the capture-recapture data to determine site fidelity as the return of a bird to the original banding colony site in subsequent years after first capture. We measured the straight-line distance between the site where a bird was banded and the site where it was later captured or resighted using Google Maps.

\section{Results}

In 2012-2019, 278 adult birds and 5 chicks were marked with colored rings at 12 Black Tern colonies at the Kaniv water reservoir during the nesting season. During the study, 44 Black Terns were resighted or recaptured at eight colonies (table 1).

Twenty-two of those returning birds were caught directly on the nests, 22 other nesting ones were observed through binoculars, spotting scope, or on camera. By visual assessment, 28 recovered birds were male, 13 were female, and the sex of the others could not be identified.

Thus, the overall return rate was $15.8 \%$.

Most returning birds were observed in one to three years after marking. In the following years, the return rate rapidly declined (fig. 1). 
Table 1. The numbers of banded and resighted / recaptured Black Terns at Kaniv reservoir colonies during 2012-2019

\begin{tabular}{|c|c|c|c|c|c|c|c|c|c|c|c|}
\hline \multirow[t]{2}{*}{ Colonies } & \multicolumn{8}{|c|}{ Year of banding } & \multirow{2}{*}{$\begin{array}{c}\text { All } \\
\text { banded } \\
\text { birds }\end{array}$} & \multicolumn{2}{|c|}{$\begin{array}{l}\text { Resighted/ recaptured } \\
\text { birds }\end{array}$} \\
\hline & 2012 & 2013 & 2014 & 2015 & 2016 & 2017 & 2018 & 2019 & & $\begin{array}{l}\text { At the same } \\
\text { colony }\end{array}$ & $\begin{array}{l}\text { At another } \\
\text { colony }\end{array}$ \\
\hline Olgin & & & 7 & 18 & 5 & 34 & 8 & & 72 & 16 & 1 \\
\hline Dykyi & & & & & & 6 & & & 6 & 0 & 0 \\
\hline Roslavlsky-1 & 4 & & 9 & 2 & 15 & 5 & & & 35 & 2 & 7 \\
\hline Roslavlsky-2 & 15 & 8 & 23 & 2 & & 9 & & 3 & 60 & 5 & 5 \\
\hline Roslavlsky-3 & & & & 5 & & & 14 & & 19 & 0 & 0 \\
\hline Pliuty-1 & & 11 & 16 & & 7 & & & & 34 & 5 & 0 \\
\hline Pliuty-2 & & 8 & & & & & & & 8 & 1 & 0 \\
\hline Pliuty-3 & & 2 & 4 & & & & & & 6 & 0 & 2 \\
\hline
\end{tabular}

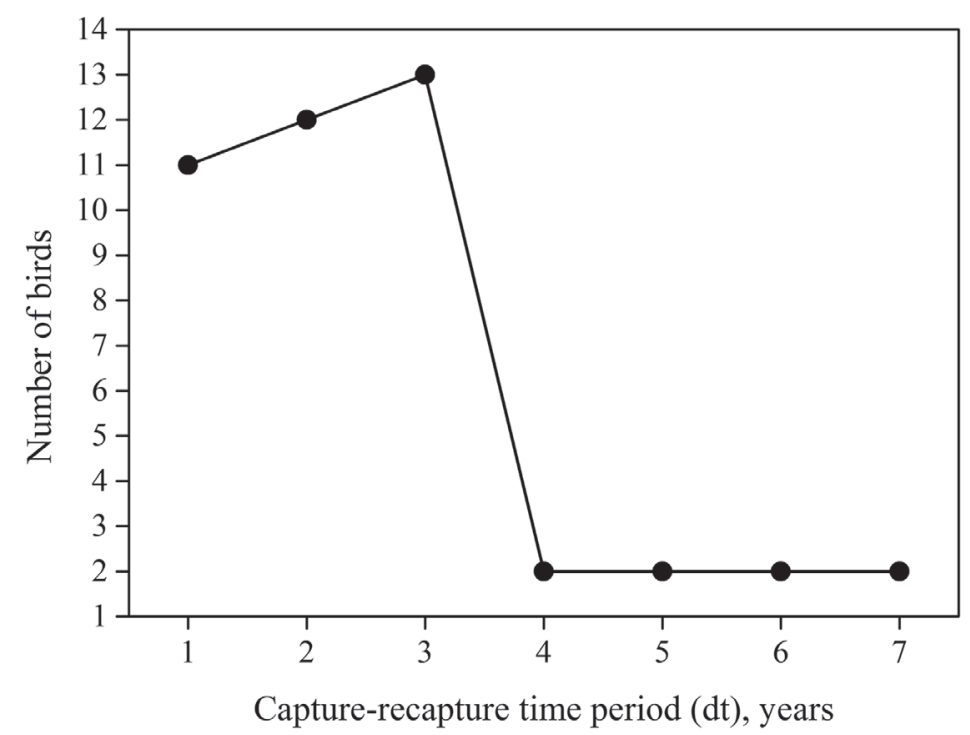

Fig. 1. The number of birds returning in different periods of time from 2012 till 2019.

29 returning terns were noted in the same colonies where the birds were initially marked, 15 birds were recorded in other colonies. The maximum distance between the colony where the bird had been marked and the colony where the return was recorded was $14 \mathrm{~km}$. Most of the birds returned to the same colony where they had been marked or to a colony less than $2 \mathrm{~km}$ away from it.

The site fidelity rate (aka \% resighted or recaptured terns which return to the same colony, suggesting site fidelity) was $66 \%$.

The distribution of bird returns according to a distance from the colonies where they had been banded was significantly different from the random one.

It is notable that the majority of recaptures and resightings occurred no farther than $2 \mathrm{~km}$ from the original colony (fig. 2). 


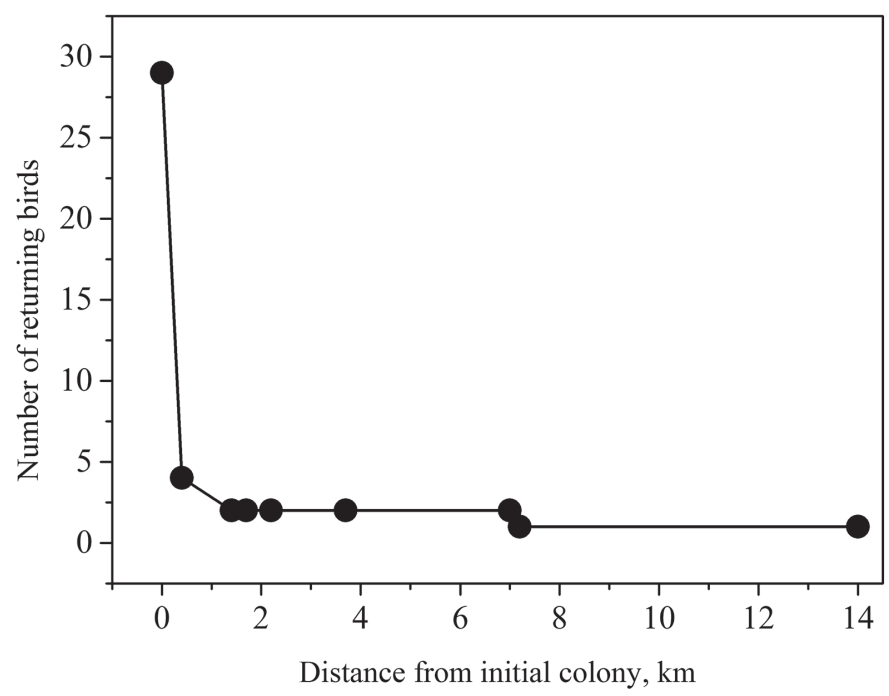

Fig. 2. The distance resighted / recaptured nesting Black Terns moved from their original colonies

An adult bird that had been ringed at the Pliuty-1 colony in June 2013, was found on the spring migration in the Danube Delta, Romania in May 2015.

\section{Discussion}

The water level does not fluctuate for more than $0.5 \mathrm{~m}$ at the Kaniv water reservoir throughout the year, which is the lowest value for all water reservoirs of the Dnipro River. The wave height does not exceed 0.2-0.4 m (Timchenko, 2006). Thus, the northern fluvial part of the water reservoir tends to be overgrown by floating-leaved aquatic plants, representatives of the family Nymphaeidae and also reed beds including Pragmites australis L., Typha angustifolia L., Sparganium erectum L., and Bolboschoenus maritimus L. (Ivanova et al., 1999).

This aquatic regime and enclosed habitats shaped by floating vegetation provide favorable conditions for the Black Tern to establish the colonies. The Black Tern colonies of the Kaniv water reservoir are built on tufts of floating aquatic vegetation and floating mats of rotting and withered aquatic vegetation (Sagittaria sagittifolia, Sparganium erectum, Potamogeton perfoliatum and Potamogeton lucens, Trapa natans), and Nymphaea candida, Nymphaea alba and Nuphar lutea overgrowing.

First clutches are laid on the substrate of floating plant mats as early as the first half of May. The hatching occurs at the end of May and the beginning of June. However, a colony may be mostly or fully destroyed by spring storms and rains, which at the Kaniv water reservoir usually happen in the second half of May. Some of the birds that have lost their clutches leave the colony to start a new one and lay eggs again. At such secondary colonies the chicks hatch at the end of June and the beginning of July.

For example, a bird marked KC banded at the Olgin colony in May, 2014, was recaptured nesting in the same colony in May, 2017. However, the colony was destroyed by a very strong storm in the second half of May. In June 2017, KC was caught on a nest with a replacement clutch at a colony near the Dykyi Island, $3.7 \mathrm{~km}$ from the original Olgin Island colony.

The marked birds were found at eight colonies, five of which are stable nesting sites. Here, the birds choose the same area every year. Dykyi, Pliuty- 2 and Roslavlsky- 3 colonies are unstable and do not function every year. 
Particularly, the Pliuty-2 colony is mostly unprotected from waves because it is located on open water. In contrast, Roslavlsky-3 and Dykyi colonies are secondary, formed by birds, which try to reproduce again after abandoning the destroyed primary colonies.

The overall site fidelity rate in the Roslavlsky- 1 colony is $22 \%$, meaning that most of the birds banded here were found in different colonies. The reason for this is that the Roslavlsky-1 colony is located in thickets of Sparganium erectum on open water, and is strongly affected by storms and rains in May. Among nine bird returns, seven were noted at other colonies including five returns in the nearby Roslavlsky- 2 colony (400 m away from the Roslavlsky-1) and two in Roslavlsky-3 colony. $50 \%$ of returns for the birds banded in Roslavlsky-2 colony were recorded in Roslavlsky-3 colony.

Roslavlsky-3 is a secondary colony founded in June by the birds from the neighboring colonies Roslavlsky-1 and 2, after the clutches had been lost due to harsh weather conditions. All colonies are located no farther than $400 \mathrm{~m}$ from each other (fig. 3).

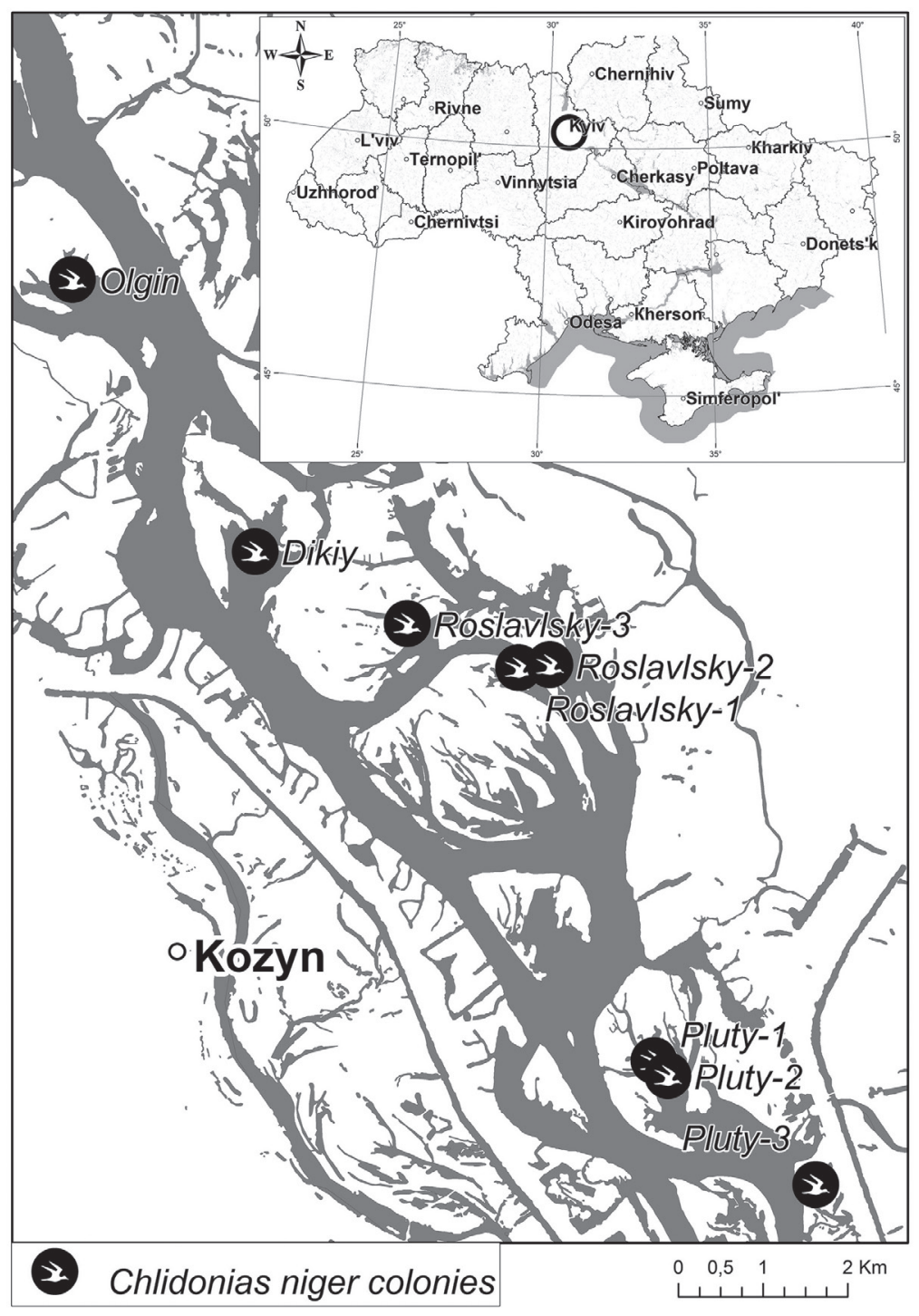

Fig. 3. The distribution of Black Tern colonies at the northern part of Kaniv water reservoir. The only colonies shown here are those where the returns of birds, which had been marked in 2012-2019, were recorded. 
According to the data from the Netherlands where Black Tern demonstrates a high site-fidelity rate adult birds can move and be recaptured subsequently at a distance about $400 \mathrm{~m}$ in some cases (van der Winden, 2004).

Thus, there is a constant exchange of birds between the three nearby colonies at Roslavlsky Island during a renewed reproduction period in June. The birds from a destroyed colony move to a less disturbed one. For example, five marked birds left the Roslavlsky-1 colony in 2014 and joined the neighboring Roslavlsky-2 colony. In 2016, birds from a partially destroyed Olgin colony founded a new nesting place near Dykyi Island.

Given the observations, the site fidelity rate for the bird colonies around Roslavlsky Island can be taken as high. However, the vulnerability to weather conditions is a destabilizing factor for the colonies and causes an increased level of bird exchange, hampering site fidelity.

Twelve bird returns from three colonies near that island were recorded for the same group of colonies at a distance about $400-500 \mathrm{~m}$ from each other. Only four birds were found in other colonies located farther than $2 \mathrm{~km}$ away.

Thus, considering the group of colonies around Roslavlsky Island as one site where birds move after their original colonies are destroyed, the overall level of the Black Terns site fidelity is $77 \%$ in the fluvial part of the Kaniv water reservoir.

The tendency to move not far away from the initial nest locations for the production of new clutches after previous reproduction attempts have failed can also be observed for a number of Laridae species with high site fidelity rate (Stenhouse, Robertson, 2005).

The highest site fidelity rate $(94 \%)$ and the highest return rate during the eight years of the study was found for the birds in the Olgin colony. This can be explained by the colony's location being well protected against a destructive impact of storms and waves. Birds from this colony do not disperse over the water reservoir to establish new colonies and lay the replacement clutches.

The productivity of Black Terns in the Olgin colony was 1.7-2 nestlings in the first clutches and 0.4 nestlings in the replacement clutches in different years of our study. Similar results are noted for the neighboring Pokal-1 colony in 2009-2011: 1-2.1 nestlings in the first clutches, and 0.5 hatchlings in the replacement ones (Atamas', 2011). In contrast, the reproduction coefficient ranged from 0.5 to 0.8 for the first clutches laid by the birds in the least protected Roslavlsky-1 colony.

Site fidelity can be affected by low productivity when the first clutch is lost at the earliest stage under stable conditions (Naves et al., 2006). On the other hand, high site fidelity rate can be found in low-quality habitats, for example, with high predator pressure (Schmidt, 2001). The Black Tern in the Netherlands demonstrates relatively low fledgling success and high level of site fidelity simultaneously in some cases(van der Winden, 2004). When birds show a high site fidelity rate in unstable habitats that get destroyed together with colonies, an "ecosystem trap" may occur (Shealer, 2007; Tims et al., 2004; Sánchez et al., 2004). A low level of productivity in Black Tern colonies established in low-quality ecosystems is likely to wipe out the ability of a nesting group to sustain itself and exist without significant immigration of birds from different nesting groups. The number of Black Terns in the Kaniv water reservoir nesting groups increased constantly during the study period. When the first clutches remain undestroyed, the productivity level is also quite high. Its mean rate is similar to the one found in optimal habitats (river in elandscapes) in the colonies in Western Europe (van der Winden et al., 2004).

The immigration rate of Black Terns to the Middle Dnipro nesting group and its impact on the population stability is yet to be defined. 


\section{Conclusion}

The site fidelity rate of adult Black Terns in the Kaniv water reservoir is affected by bird relocations and building secondary colonies after losing original ones, and varies substantially between colony sites. The same pattern is noted for other tern species in unstable habitats (Sánchez et al., 2004; Devline et al., 2008).

Black Terns have a high site fidelity rate and high productivity of the first clutches in colonies established in stable and protected habitats. Bird colonies are more vulnerable in unstable environment. So, birds tended to nest in different colonies in the same area after losing their first clutches, but not farther than $2 \mathrm{~km}$ away from them.

\section{References}

Atamas', N. S. 2011. Changes in community structure of Chlidonias terns in connection with macrophyte communities transformation on water reservoirs of Middle Dnieper river. Bird ecology: species, communities, interrelations. Proceedings of the meeting commemorating the 150th anniversary of the birth of Nikolay N. Somov (1861-1923) 1-4 December 2011, Kharkov, Ukraine, 301-315 [In Russian].

Bokotey, A. A., Dzyubenko, N. V., Horban, I. M., Kuchinska, I. V., Basta, A.-T. V., Pohranychnyy ,V. A., Buchko, V. V., Senyk, M. A. 2010.Breeding avifauna of the Upper Basin of the Dniester. Lviv, 1-440 [In Ukrainian].

Bried, J., Jouventin, P. 2001. Site and mate choice in seabirds: an evolutionary approach. In: Schreiber, E. A., Burger, J. eds. Biology of Marine Birds. CRC Press, Boca Raton, 263-306.

Coulson, J. C. 2016. A review of philopatry in seabirds and comparisons with other waterbird species. Water birds, 39 (3) 229-240.

Devlin, C. M., Diamond, A. W., Kress, S. W., Hall, C. S., Welch, L. 2008. Breeding dispersal and survival of Arctic terns Sterna paradisaea nesting in the Gulf of Maine. Auk, 125 (4), 850-858.

Dzyubenko, N. V. 2005. Features of temporary structure of Black Tern settlements in the basin of the Upper Dniester. Nauk. zapyskyDerzh. pryrod. muzeyu. Lviv, 21, 65-76 [In Ukrainian].

Greenwood, P. J. 1982. The natal and breeding dispersal of birds. Ann. Rev. Ecol. Syst., $13,1-21$.

Francesiaz, C., Farine, D., Laforge, C., Bechet, A., Sadoul, N., Besnard, A. 2017. Familiarity drives social philopatry in an obligate colonial breeder with weak interannual breeding-site fidelity. Aminal Behaviour, 124, 125-133.

Ivanova, I. Yu., Dyachenko, T. N., Nabatova, Ye. A. 1999. Landscape and Cenotic Analysis of the Plant Cover of the Kanev Reservoir. Hydrobiological Journal, 35 (2), 26-35 [In Russian].

McNicholl, M. K. 1975. Larid site tenacity and group adherence in relation to habitat. Auk, 92 (1), 98-104.

Meier-Peithmann, W. 2005. Die Trauerseeschwalbe Chlidonias niger in der Elbaue des Hannoverschen wendlandes. die Vogelwelt, 126, 219-225.

Naves, L. C., Monnat, J. Y., Cam, E. 2006. Breeding performance, mate fidelity, and nest site fidelity in a longlived seabird: behaving against the current? Oikos, 115, 263-276.

Sánchez, J. M., Corbacho, C., Muñoz del Viejo, A., Parejo, D. 2004. Colony-site tenacity and egg crypsis in the gull-billed tern. Waterbirds, 27, 21-30.

Shealer, D. 2007. Population dynamic of Black Terns breeding in Southeasten Wisconsin, 1999-2007. Passenger Pigeon, 69, 471-478.

Stenhouse, I. J., Robertson, G. J. 2005. Philopatry, site tenacity, mate fidelity, and adult survival in Sabine'sgulls. The Condor, 107, 416-423.

Schmidt, K. A. 2001. Site fidelity in habitats with contrasting levels of nest predation and blood parasitism. Evo. Ecol. Res., 3, 633-648.

Switzer, P. V. 1993. Site fidelity in predictable and unpredictable habitats. Evolutionary Ecology, 7 (6), 533-555.

Timchenko, V. M. 2006. Ecological hydrology of the water reservoirs of Dnieper river. Hydrobiological journal, 42 (3), 81-96 [In Russian].

Tims. J., Nisbet, I. C. T., Friar, M. S., Mostello, C., Hatch, J. 2004. Characteristics and performance of common terns in old and newly-established colonies. Waterbirds, 27 (3), 321-332. 
Van der Winden, J. 2004. Ringonderzoek aan de Zwarte Stern Chlidonias niger in het Groene Hart. Het Vogeljaar, 52 (4), 155-161.

Van der Winden, J., Beintema, A. J., Heemskerk, L. 2004. Habitat-related Black Tern Chlidonias niger breeding success in the Netherlands. Ardea, 92 (1), 53-62.

Received 23 May 2020

Accepted 25 August 2020 